\title{
Feasibility Study of Solar and Wind Energy in Remote Islands (Gili Labak Madura)
}

\author{
Mu'alim $^{1}$, Sabarudin Akhmad ${ }^{1}$, Anis Arendra ${ }^{1}$, Khoirul Hidayat ${ }^{2}$ and M Adhi Prasnowo ${ }^{3}$ \\ $\{$ mualalim@gmail.com, sabarutm@gmail.com,arendra22@yahoo.com, \\ prasnowoadhi@dosen.umaha.ac.id \} \\ ${ }^{1}$ Industrial Engineering Departement, Faculty of Engineering, University of TrunojoyoMadura, Indonesia \\ ${ }^{2}$ Agroindustrial Technology Department, Faculty of Agricultural, University of TrunojoyoMadura, \\ Indonesia \\ ${ }^{3}$ Industrial Engineering Departement, Faculty of Engineering, Universitas Maarif Hasyim Latif, Indonesia
}

\begin{abstract}
GiliLabak Island is one of the Madura's remote islands, actually has the opportunity of utilization of renewable energy source that is available abundantly throughout the year such as solar and wind energy. The utilization of both alternatives energy need feasibility analysis. First stepis collecting datas of electricity daily energy demand inGiliLabak which was gotten aproximatly $61.870 \mathrm{Kwh} /$ day. The next process performs an economical analysis for each type of solar cell package as the most economical option based on NPV and IRR analysis. After knowing the energy generated by each wind power package then will calculate how much wind power system's needed for all the electricity demand. To find out how many wind power plants (wind power plants) then the energy generated for one year/energy that will be generated from each hydropower package. Finally step was doing comparison of both two alternatives energy which the most economist. Based on economic analysis with NPV and IRR approach from several alternative power plants from solar cell and wind turbine can be concluded that alternative solar cell type $1000 \mathrm{Wp}$ polycrytaline is a very feasible alternative to be realized because it has a value of NPV $>0$ while from the value of IRR- $27 \%$ is the highest of all alternatives that have IRR value above the discount factor value (14\%).
\end{abstract}

Keywords: GiliLabak,Madura,Electric Energy Demand,Solar and Wind Alternative Energy Potential,SHS, Wind Energy System,Feasibility Study, Economical Analysis.

\section{Introduction}

World energy consumption levels are forecast to increase by 70 percent $\%$ between 2000 and 2030. Fossil energy sources, which account for $87.7 \%$ of the world's total energy demand, are expected to decline due to the absence of new sources of reserves(ApS, 2005; Lubis, 2011). Fossil-based energy resources worldwide are estimated to be only 40 years for petroleum, 60 years for natural gas and 200 years for coal. Besides, the increasing demand of fossil energy give other impacts of global warming and environmental pollution that is already at a very alarming level.

Madura is one area in East Java that has great potential in national and even international scale both in terms of natural tourism and fisheries(Muhsoni and Efendy, 2016). This is in line with the master plan of Madura industrialization post Suramadu. In support of the program, Madura must prepare all its structures and infrastructures including the provision of adequate, cheap, independent, renewable and environmentally friendly energy source(Hansen and Hansen, 2007; Lubis, 2011; Michalak and Zimny, 2011). That way will stimulate investor interest to invest in Madura. 
Gili Labak Island is one of the Madura's remote islands where inhabited of 35 family or 105 people which currently have problem the aviability of electric energy. On the other hand, Gili Labak Island actually has the opportunity of utilization of renewable energy source that is available abundantly throughout the year such as solar energy by using solar cell modules and wind energy by using wind turbine module(Kristianto, 2010; Sitompul, 2011; Goudarzi and Zhu, 2013). In the framework of utilization of both alternatives energy is required technically and economically feasibility analysis as solution of Gili Labak Island's fulfillment of electric energy.

\section{Methods}

\subsection{Data Collection of Daily Electricity Demand}

Data collection of electricity demand in the GiliLabak Islands was done by conducting direct interviews of each home electrical appliances which they need and how many hours a day approximate its used. Based on the results of the interview then made an estimate of the electricity needs of each household by setting some standard electrical power equipment eg 10 watts for living room lamp, 125 watts for water pump and 125 watts for television. After the estimated total electricity needs of each house then summed to the total electricity demand of GiliLabak community.

\subsection{Collection of Intensity Data and Duration of Daily Solar Lighting}

Monthly data of solar intensity in GiliLabak area is obtained from Meteorology Climatology And Geophysics Agency (BMKG) represents the average of the sun intensity for the period 2015 until 2016 of the GiliLabak Madura.

\subsection{Daily Wind Speed Data Collection}

Data of wind speed in Gili Labak area is obtained from Meteorology Climatology And Geophysics Agency (BMKG).The periode of the data for two years from 2015 until 2016.

\subsection{Data Collection Types Of Solar Cell Technology And Wind Turbines}

Data collection technology of solar cells and wind turbines are available in the market related to technical specifications and the price through the media internet, newspapers and other media.

The result of Solar Home System (SHS) and wind power system in the market are as shown in table 1 and table 2 .

Table 1:Technology package ofsolarhomesystem.

\begin{tabular}{ccll}
\hline No & Package Type & Package (Wp) & Price (IDR) \\
\hline \multirow{2}{*}{1} & Monocrystalline & 50 & $3.300 .000,-$ \\
\cline { 3 - 4 } & & 100 & $7.500 .000,-$ \\
\cline { 3 - 4 } & & 200 & $11.500 .000,-$ \\
\cline { 3 - 4 } & & 10.000 & $660.000 .000,-$ \\
\hline 2 & Polycrystalline & 50 & $3.300 .000,-$ \\
\cline { 3 - 4 } & & 100 & $6.700 .000,-$ \\
\cline { 3 - 4 } & & 200 & $13.000 .000,-$ \\
\cline { 2 - 3 } & & 10.000 & $49.000 .000,-$ \\
\hline
\end{tabular}


Table 2:Technology package ofsolarhomesystem.

\begin{tabular}{ccc}
\hline No & Package (W) & Price (IDR) \\
\hline 1 & 1000 & 30.000 .000 \\
\hline 2 & 2000 & 45.600 .000 \\
\hline 3 & 3000 & 75.500 .000 \\
\hline
\end{tabular}

\subsection{Real location at the area that feasible for Develop Wind and Solar Energy Sistem}

Real location survey by measuring solar intensity,Duration of Daily Solar Lighting and Wind Speed Data at few spot sample at the area as potential location that becomes the possibility of placement of solar cells and wind turbines in the Gili Islands of Labak to be analyzed by performing direct measurements of the intensity of solar radiation and wind speed of the greatest. The potential location of solar and wind energy system where placed are shown in figure 1 and figure 2.

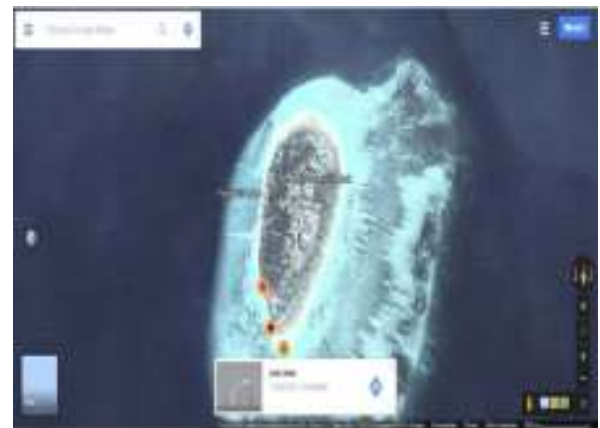

Fig. 1. Some potential spot location for wind energy system.

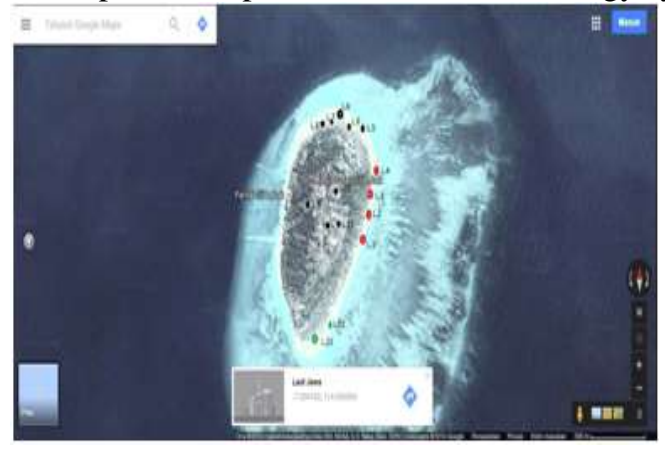

Fig. 2. Some potential spot location for solar energy system.

\subsection{Calculation of Alternative Wind and Solar Energy Potential and Economic Analysis with NPV and IRR Approach}

Calculation of Alternative Wind and Solar Energy Potential in theoretical analysis of solar and wind alternative energy potentials in Gili Labak Islands to meet the electricity needs of the community is based on data of intensity and duration of solar irradiance and daily data of wind speed in Gili Labak for 2 years and alternative energy which is more suitable based on technical specification available on the market. Furthermore, economic analysis using Net 
Present Value (NPV) and Internal Rate of Return (IRR) based on investment cost with 25 year analysis time(Kodoatie, 1995; Pujawan, 2004).

\subsection{Selection of best technology alternatives based on the best value of NPV and IRR approach}

Finally step was doing comparison of both two alternatives energy which the most economist.

\section{Result}

First Step in this study began with data collecting of daily energy demand of electricity in GiliLabak which from the observation was gotten total electrical energy demand in GiliLabakaproximatly $61.870 \mathrm{Kwh} /$ day. The next was calculated of solar and wind alternative energy potential for solve electrical energy demand. The solar alternative with solar power system (SHS) in the market is $50 \%$ of home solar system (SHS) required must be powered twice the total energy demand In GiliLabak is $123.74 \mathrm{Kwh}$.

Based on BMKG data SHS working time / average duration of sun exposure for 2 years from 2015 to 2016 it's about 8,140 hours every day. So the maximum power required SHS about $15202.360 \mathrm{Kwh}$.Then calculated the SHS demand of each package that available on the market such as the type of package $50 \mathrm{Wp}, 100 \mathrm{Wp}, 1000 \mathrm{Wp}$ and $10000 \mathrm{Wp}$.

From the calculation process was gotten number of SHS needed and its price as shown in table 3.

Table 3. Number of SHS needed and its price.

\begin{tabular}{lllll}
\hline No & Package Type & Package $(\mathrm{Wp})$ & Needed (packge) & Price (IDR) \\
\hline \multirow{2}{*}{1} & Monocrystalline & 50 & 37 & $123.269 .569,-$ \\
\cline { 3 - 5 } & & 100 & 19 & $140.079 .056,-$ \\
\cline { 3 - 5 } & & 200 & 9 & $107.393 .943,-$ \\
\cline { 3 - 5 } & & 10.000 & 1,0 & $220.000 .000,-$ \\
\hline \multirow{2}{*}{ Polycrystalline } & 50 & 37 & $123.269 .569,-$ \\
\cline { 3 - 5 } & & 100 & 19 & $125.137 .290,-$ \\
\cline { 3 - 5 } & 200 & 9 & $99.000 .000,-$ \\
\cline { 3 - 5 } & 10.000 & 2,0 & \\
\hline
\end{tabular}

The next process performs an economical analysis for each type of solar cell package as the most economical option based on NPV and IRR analysis.

The Calculation process of wind potential energy began with calculating the total electrical energy demand for one year (360 days) is $21986.64 \mathrm{KWh}$. Then calculate the potential of electrical energy that can be generated by type of power plant packages which sold in the market such as the 1000 watt package with a rotor diameter of $2.7 \mathrm{~m}, 2000$ watt with $3.2 \mathrm{~m}$ and 3000 watt package with $4.5 \mathrm{~m}$.

Based on rotor diameter;

If $\eta \quad=$ total efficiency $(0.30)$ and

$\mathrm{WPD}=$ site-specific power $(\mathrm{W} / \mathrm{m} 2)$,

then wind turbine energy in $\mathrm{kWh}$,

$\mathrm{E} \quad=\eta$. (WPD).A.t

$=\eta \cdot 1 / 2 \rho \mathrm{V} 3 . \mathrm{A} .8 .760$

With; 
t $\quad=$ number of hours in 1 year $=8760$,

while $\mathrm{A}=$ the area of rotor sweep $(\mathrm{m} 2)$

ie: for the flat axis, $A=(\pi / 4) D 2)$.

The Calculation of wind potential energy in $\mathrm{kWh}$ that can be generated by type of wind power system which sold in the market was done for each type such as the 1000 watt package (rotor diameter $\mathrm{R}=2.7 \mathrm{~m}, \mathrm{E}=683.624 \mathrm{KWh}), 2000$ watt $(\mathrm{R}=3.2 \mathrm{~m}, \mathrm{E}=960.262 \mathrm{KWh}$ ) and 3000 watt $(\mathrm{R}=4.5 \mathrm{~m}, \mathrm{E}=1898.957 \mathrm{KWh})$.

After knowing the energy generated by each wind power package then will calculate how much wind power system's needed for all the electricity demand. To find out how many wind power plants (wind power plants) then the energy generated for one year / energy that will be generated from each hydropower package.

From the calculation process was gotten number of wind power system needed and its price as shown in table 4.

Table 4. Number of wind power system needed and its price.

\begin{tabular}{lll}
\hline Package (Wp) & Price (IDR) & Wind power system Needed \\
\hline 1000 & $30.000 .000,-$ & 33 \\
\hline 2000 & $45.600 .000,-$ & 23 \\
\hline 3000 & $75.500 .000,-$ & 12 \\
\hline
\end{tabular}

After knowing of the number of wind power system needed then calculate the total cost of each packet that followed by conducting an economic analysis for each type of wind energy power plant package as the most economical option based on NPV and IRR analysis. Finally step was doing comparison of both two alternatives energy which the most economist.

Based on economic analysis with NPV and IRR approach from several alternative power plants from colar cell and wind turbine can be concluded that alternative solar cell type 1000 Wppolycrytaline is a very feasible alternative to be realized because it has a value of NPV>0 while from the value of IRR- $27 \%$ is the highest of all alternatives that have IRR value above the discount factor value (14\%). The detail analyisis data of NPV and IRR value as shown in table 5 and table 6 .

Table 5. Viable alternative for NPV analysis.

\begin{tabular}{llll}
\hline \multicolumn{4}{l}{ Viable alternative for NPV analysis } \\
\hline No & Alternative & NPV value & information \\
\hline 1 & mono crystaline $50 \mathrm{Wp}$ & $\mathrm{Rp51.928.496}$ & feasible \\
\hline 2 & mono crystaline $100 \mathrm{Wp}$ & $\mathrm{Rp} 50.749 .555$ & feasible \\
\hline 3 & mono crystaline $200 \mathrm{Wp}$ & $\mathrm{Rp} 73.130 .062$ & feasible \\
\hline 4 & mono crystaline $10.000 \mathrm{Wp}$ & $-\mathrm{Rp} 35.994 .817$ & not feasible \\
\hline 5 & poly crystaline $50 \mathrm{Wp}$ & $\mathrm{Rp} 58.263 .847$ & feasible \\
\hline 6 & poly crystaline $100 \mathrm{Wp}$ & $\mathrm{Rp53.299.236}$ & feasible \\
\hline 7 & poly crystaline $200 \mathrm{Wp}$ & $\mathrm{Rp59.122.157}$ & feasible \\
\hline 8 & poly crystaline $1000 \mathrm{Wp}$ & $\mathrm{Rp} 84.888 .095$ & feasible \\
\hline 9 & PLTA 1000 watt & $-\mathrm{Rp} 784.776 .933$ & not feasible \\
\hline 10 & PLTA 2000 watt & $-\mathrm{Rp} 888.310 .826$ & not feasible \\
\hline 11 & PLTA 3000 watt & $-\mathrm{Rp747.576.477}$ & not feasible \\
\hline
\end{tabular}


Table 6. Viable alternative for NPV analysis.

\begin{tabular}{llll}
\hline IRR & & & \\
\hline No & Alternatives & Discountfactor & IRR \\
\hline 1 & monocrystaline $50 \mathrm{Wp}$ & $14 \%$ & $21 \%$ \\
\hline 2 & monocrystaline $100 \mathrm{Wp}$ & $14 \%$ & $21 \%$ \\
\hline 3 & monocrystaline $200 \mathrm{Wp}$ & $14 \%$ & $25 \%$ \\
\hline 4 & monocrystaline $10000 \mathrm{Wp}$ & $14 \%$ & $11 \%$ \\
\hline 5 & polycrystaline $50 \mathrm{Wp}$ & $14 \%$ & $22 \%$ \\
\hline 6 & polycrystaline $100 \mathrm{Wp}$ & $14 \%$ & $21 \%$ \\
\hline 7 & polycrystaline $200 \mathrm{Wp}$ & $14 \%$ & $22 \%$ \\
\hline 8 & polycrystaline $1000 \mathrm{Wp}$ & $14 \%$ & $27 \%$ \\
\hline 9 & PLTA 1000 W & $14 \%$ & $-2 \%$ \\
\hline 10 & PLTA 2000 W & $14 \%$ & \#NUM! \\
\hline 11 & PLTA 3000 W & $14 \%$ & \#NUM! \\
\hline
\end{tabular}

\section{Conclusions}

The conclusions of this study are as follows. Based on economic analysis with NPV and IRR approach from several alternative power plants from colar cell and wind turbine can be concluded that alternative solar cell type $1000 \mathrm{Wppolycrytaline} \mathrm{is} \mathrm{a} \mathrm{very} \mathrm{feasible} \mathrm{alternative} \mathrm{to}$ be realized because it has a value of NPV> 0 while from the value of IRR-27\% is the highest of all alternatives that have IRR value above the discount factor value (14\%).

\section{Acknowledgements}

This work is partly supported by the Department of Industrial Engineering, Faculty of Engineering, Trunojoyo University Madura

\section{References}

[1] ApS, B. T. M. C. (2005) 'International wind energy development', World Market update 2004, Forecast 2005-2009.

[2] Goudarzi, N. and Zhu, W. D. (2013) 'A review on the development of wind turbine generators across the world', International Journal of Dynamics and Control. Springer, 1(2), pp. 192-202.

[3] Hansen, A. D. and Hansen, L. H. (2007) 'Wind turbine concept market penetration over 10 years (1995-2004)', Wind energy. Wiley Online Library, 10(1), pp. 81-97.

[4] Kodoatie, R. J. (1995) 'Analisis Ekonomi Teknik', Penerbit Andi Offset, Yogyakarta.

[5] Kristianto, A. N. (2010) 'Studi Kelayakan Investasi Pembangkit Listrik Tenaga Surya (PLTS) Di Pulau Biaro Dengan Menggunakan Metode Real Option’. Universitas Indonesia. Fakultas Ekonomi.

[6] Lubis, A. (2011) 'Energi terbarukan dalam pembangunan berkelanjutan', Jurnal Teknologi Lingkungan, 8(2).

[7] Michalak, P. and Zimny, J. (2011) 'Wind energy development in the world, Europe and Poland from 1995 to 2009; current status and future perspectives', Renewable and Sustainable Energy Reviews. Elsevier, 15(5), pp. 2330-2341.

[8] Muhsoni, F. F. and Efendy, M. (2016) 'ANALISI DAYA DUKUNG PEMANFAATAN PULAU GILI LABAK DENGAN MENGGUNAKAN SISTEM 
INFORMASI GEOGRAFIS', Prosiding Semnas Perikanan dan Kelautan VI, UB.

[9] Pujawan, I. N. (2004) Ekonomi Teknik, Penerbit Guna Widya. Surabaya.

[10] Sitompul, R. (2011) 'Manual Pelatihan Teknologi Energi Terbarukan yang Tepat Untuk Aplikasi di Masyarakat Pedesaan', Jakarta: PNPM Support Facility (PSF), pp. 45-75. 